\title{
STUDIA I PRACE
}

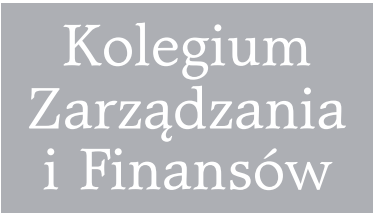

$176 / 2019$

S. $111-135$

Szkoła Główna Handlowa w Warszawie

Oficyna Wydawnicza SGH

kolegia.sgh.waw.pl

Karol Matczak

Stowarzyszenie Investhink

Jakub Wojciechowski

Stowarzyszenie Investhink

Czesław Martysz

Kolegium Zarządzania i Finansów

Szkoła Główna Handlowa w Warszawie

\section{Inwestowanie zrównoważone w zarządzaniu portfelem inwestycyjnym}

\section{Streszczenie}

Inwestowanie zrównoważone to selekcja spółek i emitowanych przez nie instrumentów do budowy portfela inwestycyjnego ze względu na ocenę ich odpowiedzialnego (etycznego) działania i budowy tzw. dobra społecznego. Inwestycje zrównoważone stanowią już ponad 25\% wartości wszystkich aktywów inwestycyjnych świata, a największe aktywa są zarządzane zgodnie z tym podejściem w Europie. Inwestor może mieć trudności w ocenie, czy przyjęcie przez fundusz kryteriów zrównoważonego inwestowania jest zabiegiem marketingowym, opartym wyłącznie na zapisie w statucie danego funduszu, czy rzeczywiście ważnym elementem procesu inwestycyjnego. Celem niniejszego artykułu jest ukazanie znaczenia i wpływu inwestowania zrównoważonego na zarządzanie portfelami inwestycyjnymi. Ponad 90\% badań dotyczących inwestycji społecznie odpowiedzialnych nie wskazało negatywnego wpływu stosowania kryteriów ESG (inwestowanie według kryteriów środowiskowych, społecznych i związanych z ładem korporacyjnym) na wyniki finansowe spółek. Implementacja kryteriów ESG w działalności spółek, tworzenie polityk odpowiedzialnego inwestowania i publiczne dzielenie się raportami z tej działalności przynosi spółkom wymierne korzyści finansowe. Rynek inwestowania 
zrównoważonego jest zatem potrzebny i wysoce prawdopodobne, że będzie się dalej dynamicznie rozwijać. Najważniejsze inicjatywy z zakresu inwestowania zrównoważonego w Polsce to stworzenie RESPECT Index, badania Stowarzyszenia Emitentów Giełdowych nad kryteriami ESG oraz wprowadzenie Standardu Informacji Niefinansowych.

Słowa kluczowe: inwestowanie społecznie odpowiedzialne, inwestycje zrównoważone, fundusze inwestycyjne, SRI, ESG

Kody klasyfikacji JEL: M14, O16, G11, G15

\section{Wprowadzenie}

Od początku XXI w. na świecie obserwuje się dynamiczny wzrost inwestycji odpowiedzialnych społecznie, zwanych również inwestycjami zrównoważonymi. Jednym z głównych katalizatorów tego trendu był globalny kryzys finansowy z 2008 r., który nadwyrężył zaufanie inwestorów do instytucji finansowych i podważył zasadność czysto finansowych kryteriów inwestowania. Trudno jednoznacznie ocenić, czy rosnąca popularność spółek deklarujących społeczną odpowiedzialność to tylko przejściowa moda, zainicjowana przez zarządzających aktywami, chcących odzyskać nadszarpnięte kryzysem zaufanie swoich klientów, czy też nowy paradygmat inwestowania, wynikający z powszechnej potrzeby głębokiego przemodelowania klasycznej teorii finansów na podstawie czynników społeczno-etycznych.

Celem niniejszego artykułu jest ukazanie znaczenia i wpływu inwestowania zrównoważonego na zarządzanie portfelami inwestycyjnymi. Poszczególnymi etapami realizacji powyższego celu będą próby odpowiedzi na poniższe pytania.

1. Czym jest inwestowanie zrównoważone?

2. Jakie są najważniejsze kryteria uznawania spółek za społecznie odpowiedzialne? Na ile kryteria te są kwantyfikowalne, a na ile uznaniowe?

3. Jakie są główne charakterystyki rynku inwestowania zrównoważonego (SI/SRI)?

4. Czy inwestycje zrównoważone generują niższe stopy zwrotu niż inwestycje klasyczne?

5. Jakie korzyści przynosi spółkom stosowanie zasad zrównoważonego rozwoju/ESG?

6. Jakie są główne bariery i perspektywy rozwoju inwestycji zrównoważonych w Polsce?

Teza artykułu brzmi: w kontekście zarządzania portfelem inwestycyjnym stosowanie inwestycji zrównoważonych nie musi być obarczone dodatkowym kosztem i być mniej efektywne od inwestycji klasycznych. Implementacja kryteriów ESG w działalności spółek, tworzenie polityk odpowiedzialnego inwestowania i publiczne dzielenie się raportami ze swojej działalności w tym obszarze przynosi im w praktyce wymierne korzyści finansowe, co może stanowić istotne kryterium uwzględniania tych spółek w portfelach inwestycyjnych. Czynniki te sprawiają, że zarządzanie aktywami z uwzględnianiem inwestycji zrównoważonych jest potrzebne i ma szansę się dynamicznie rozwijać. 


\section{Definicja inwestowania zrównoważonego}

W koncepcji racjonalnego inwestora ${ }^{1}$, wywodzącej się z klasycznej teorii finansów ${ }^{2}$, decyzje inwestora są zdeterminowane wyłącznie poprzez czynniki finansowe ${ }^{3}$, a czynniki społeczne i moralne, takie jak wiara, dobro społeczne czy etyka, są tu całkowicie ignorowane. Inwestowanie zrównoważone (ang. sustainable investments, SI) to strategia inwestowania, w której determinanty behawioralne zyskują przewagę wobec kryteriów finansowych. Kluczowym czynnikiem wyboru portfela inwestycyjnego w koncepcji SI jest bowiem selekcja spółek ze względu na ocenę ich odpowiedzialnego (etycznego) działania. Celami takiego inwestowania, oprócz maksymalizacji zysku, stają się również interesy innych osób oraz tzw. dobro społeczne. Jak podkreśla A. Duliniec [2015] zamiennie z pojęciem SI używa się innych określeń, takich jak inwestycje etyczne, inwestycje zielone (ekologiczne), inwestowanie odpowiedzialne społecznie (ang. Socially Resposible Investing, SRI) a także ESG, tj. inwestowanie według kryteriów środowiskowych, społecznych i związanych z ładem korporacyjnym (Environmental, Social, Governance, ESG).

Sformułowanie zrównoważony rozwój oznacza strategię rozwoju polegającą na aktywnym zaangażowaniu we wdrażanie standardów odpowiedzialności społecznej przedsiębiorstw [Jamróz, 2017] $]^{4}$. Chodzi o tzw. złoty środek i równowagę pomiędzy interesem przedsiębiorstwa (najczęściej jest nim maksymalizacja zysku lub udziału w rynku) oraz interesem społeczeństwa i otoczenia przedsiębiorstwa. Nowa Ekonomia Ekologiczna, zrodzona w berlińskiej Wyższej Szkole Ekonomicznej [Rogall, 2010], nie uzyskała szerokiej akceptacji pomimo przeszło 20-letniej historii. Jednak pokłosiem podejmowanych na forach międzynarodowych dyskusji na temat zrównoważonego rozwoju był światowy szczyt w Rio de Janeiro w 1992 r., a emanacją przyjęte tam wytyczne. Tam też pojawił się termin polityka ochrony środowiska i przyjęto 26 zasad $^{5}$, które powinny kierować rozwojem na poziomie globalnym. Wzrost gospodarczy traci zatem prym na rzecz zrównoważonego rozwoju.

Według R. Spareksa [2002] CSR (ang. corporate social responsibility) i SRI to dwie strony tego samego medalu - zrównoważoną i odpowiedzialną społecznie aktywność gospodarczą można rozpatrywać z punktu widzenia przedsiębiorstwa oraz z punktu widzenia inwestorów

\footnotetext{
1 Człowiek racjonalny podejmuje konsekwentne działania zmierzające do stałego podnoszenia poziomu swojego dobrobytu i tzw. oczekiwanej użyteczności, co czyni, analizując informacje za pomocą obiektywnego aparatu matematycznego.

2 Jest to nurt ekonomii neoklasycznej, tzw. mainstream. Jego fundamentami są paradygmat człowieka racjonalnego (tzw. homo oeconomicus) oraz hipoteza rynków efektywnych; zob. [Martysz, Rzeszutek, 2016].

3 W ujęciu nowoczesnej teorii portfelowej decyzje inwestora zależą wyłącznie od ryzyka i stopy zwrotu; zob. [Martysz, Rzeszutek, 2016].

4 Wokół sformułowania „Zrównoważony rozwój” narosło wiele nieporozumień, ponieważ często jest ono błędnie rozumiane jako umiarkowane tempo wzrostu czy inwestycje w aktywa o umiarkowanym ryzyku.

5 Przykładowo, zasada nr 10 wskazuje, że ekonomiczny i społeczny rozwój jest kluczowy do zapewnienia korzystnego otoczenia dla życia i pracy człowieka oraz stworzenia warunków na Ziemi koniecznych do poprawy jakości życia. Jak widać, istotą jest poprawa jakości życia.
} 
na rynku kapitałowym. Strategia SRI to inwestowanie w spółki działające według koncepcji CSR, gdzie działalność gospodarcza przynosi korzyści nie tylko samym właścicielom i zarządzającym spółką, lecz także innym grupom interesariuszy, takich jak pracownicy, odbiorcy, dostawcy czy społeczności lokalne skupione wokół danej spółki .

W trakcie selekcji aktywów w inwestycjach SRI/ESG najczęściej stosuje się selekcję negatywną i pozytywną. Selekcja negatywna polega na eliminowaniu inwestycji związanych z tzw. branżami „grzesznymi”" , energetyką nuklearną, z wytwarzaniem produktów modyfikowanych genetycznie, dyskryminacją pracowników czy z wykorzystywaniem dzieci do pracy. Dobór aktywów do portfela może być również ściśle związany z konkretnym świato-

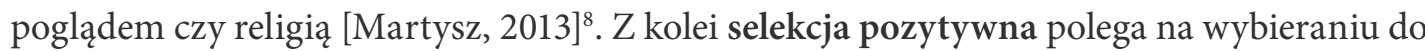
portfela spółek deklarujących stosowanie koncepcji zrównoważonego rozwoju (ang. sustainable development), społecznej odpowiedzialności biznesu oraz zasad ładu korporacyjnego (ang. corporate governance). Wydaje się, że najszerzej akceptowanym globalnym standardem klasyfikacji sposobów inwestowania odpowiedzialnego jest ten zaproponowany przez Global Sustainable Investment Alliance (GSIA) - podmiot zrzeszający siedem największych organizacji działających w obszarze SRI [GSIA, 2012]:

1) selekcja negatywna: wykluczanie z portfela inwestycyjnego lub funduszu konkretnych sektorów, spółek lub praktyk przy uwzględnieniu specyficznych kryteriów ESG,

2) selekcja pozytywna: inwestowanie na podstawie kryteriów ESG (w kategoriach absolutnych lub relatywnych względem konkurencji),

3) selekcja oparta na normach: wykorzystywanie międzynarodowych standardów (np. ONZ, OECD, ILO, UNICEF) jako podstawy do zawężenia spektrum inwestycyjnego,

4) integracja ESG: włączenie czynników ekologicznych, społecznych i ładu korporacyjnego do procesu inwestycyjnego i analizy finansowej,

5) inwestowanie tematyczne: inwestowanie środków w konkretne inicjatywy, sektory, czy spółki związane ze zrównoważonym rozwojem (np. energia odnawialna, tworzenie miejsc pracy, budownictwo komunalne, zrównoważone rolnictwo),

6) impact investing: inwestowanie na celu wykreowania konkretnych zmian społecznych lub środowiskowych, skupione głównie w na rynkach niepublicznych, np. fundusze private equity (PE) oraz venture capital (VC),

7) zaangażowanie korporacyjne i akcjonariuszy: działania skierowane na wywołanie zmian zachowań korporacji poprzez m.in. bezpośrednie zaangażowanie pracowników (np. oddolne propozycje zmian) czy aktywność akcjonariuszy (głosowanie nad uchwałami, własna inicjatywa).

\footnotetext{
6 Tym samym z koncepcją CSR wiąże się również podejmowanie decyzji ukierunkowanych na ochronę praw człowieka, praw pracowniczych oraz ochronę środowiska.

7 Są to m.in. przemysł zbrojeniowy, alkoholowy, tytoniowy, hazardowy, pornograficzny.

8 Według Koranu należy unikać praktyk biznesowych związanych z hazardem, wieprzowiną, pornografią oraz instytucji finansowych czerpiących korzyści z odsetek, czyli lichwy.
} 


\section{Rynek inwestowania zrównoważonego (SI/SRI)}

\subsection{Wielkość i struktura}

Aktywa inwestowane zgodnie z SRI mają znaczący udział w całości aktywów inwestycyjnych na świecie - szacuje się, że jest to ponad 25\% wszystkich inwestycji, a ich udział sięga od 18\% w Japonii do 63\% w Australii i Nowej Zelandii [GSIA, 2018]. Co ciekawe, wbrew udziałom poszczególnych rynków kapitałowych na świecie, to nie USA, lecz Europa jest największym rynkiem SRI pod względem nominalnym, co pokazano w tabeli 1 .

Tabela 1. Wielkość rynku SRI w poszczególnych regionach

\begin{tabular}{|c|c|c|c|c|c|c|}
\hline \multirow{2}{*}{ Region } & \multirow{2}{*}{2014} & \multirow{2}{*}{2015} & \multirow{2}{*}{2017} & \multicolumn{2}{|c|}{ Procentowy wzrost aktywów } & \multirow{2}{*}{$\begin{array}{l}\text { Średni wskaźnik } \\
\text { rocznego wzrostu } \\
\text { (CAGR) 2014-2018 }\end{array}$} \\
\hline & & & & 2014-2016 & $2016-2017$ & \\
\hline Europa (EUR) & 9885 & 11045 & 12306 & 12 & 11 & $6 \%$ \\
\hline USA (USD) & 6572 & 8723 & 11995 & 33 & 38 & $16 \%$ \\
\hline Kanada (CAD) & 1011 & 1505 & 2132 & 49 & 42 & $21 \%$ \\
\hline Australia i Nowa Zelandia (AUD) & 203 & 707 & 1033 & 248 & 46 & $50 \%$ \\
\hline Japonia (JPY) & 840 & 57056 & 231952 & 6692 & 307 & $308 \%$ \\
\hline
\end{tabular}

Komentarz: wartości aktywów podano w miliardach. W przypadku Japonii dane dla 2017 roku podano na dzień 31.03.2018. Źródło: opracowanie własne na podstawie [GSIA, 2018].

Najwyższe tempo wzrostu aktywów SRI w latach 2014-2017 zanotowano w Japonii, Australii i Nowej Zelandii, co wynika ze stosunkowo niskiej bazy (tj. wartości inwestycji w poprzednich latach). Niemniej jednak na większości analizowanych rynków dynamika wzrostu jest istotna. Najwyższy udział aktywów SRI we wszystkich aktywach w zarządzaniu w 2018 r. można było zaobserwować w Australii i Nowej Zelandii, Kanadzie i Europie (tabela 2).

Tabela 2. Udział inwestycji SRI w zarządzanych aktywach (w \%)

\begin{tabular}{|l|c|c|c|}
\hline \multicolumn{1}{|c|}{ Region } & 2014 & 2016 & 2017 \\
\hline Europa & 58,8 & 52,6 & 48,8 \\
\hline USA & 17,9 & 21,6 & 25,7 \\
\hline Kanada & 31,3 & 37,8 & 50,6 \\
\hline Australia i Nowa Zelandia & 16,6 & 50,6 & 63,2 \\
\hline Japonia & BD & 3,4 & 18,3 \\
\hline
\end{tabular}

Komentarz: W 2014 r. dane dotyczące Japonii wliczano do całej Azji, stąd brak indywidualnych danych.

Źródło: opracowanie własne na podstawie [GSIA, 2018]. 
Najczęściej wykorzystywanym sposobem inwestowania odpowiedzialnego jest selekcja negatywna (rysunek 1). Może to wynikać zarówno ze stosunkowo łatwej implementacji metod selekcji aktywów (wykluczenie konkretnych sektorów, spółek, krajów), jak i przejrzystej komunikacji do inwestorów ${ }^{9}$. Korzenie tego podejścia odnajdujemy w religiach (judaizm, chrześcijaństwo, islam, buddyzm), które piętnowały konkretne zachowania (np. lichwę) lub typ działalności. Pierwsze zinstytucjonalizowane podejście do negatywnej selekcji w inwestowaniu zaprezentowano szerzej w 1971 r., gdy uruchomiono Pax World Fund - pierwszy etyczny fundusz na świecie. Fundusz nie inwestował m.in. w producentów broni, co można było odczytywać jako protest wobec trwającej wówczas wojny wietnamskiej [Goff, 2006]. Kolejne lata przyniosły rozwój strategii określanych jako SRI [Fulton, Kahn, Sharples, 2012].

Rysunek 1. Aktywa netto SRI według strategii oraz regionu (w mld USD)

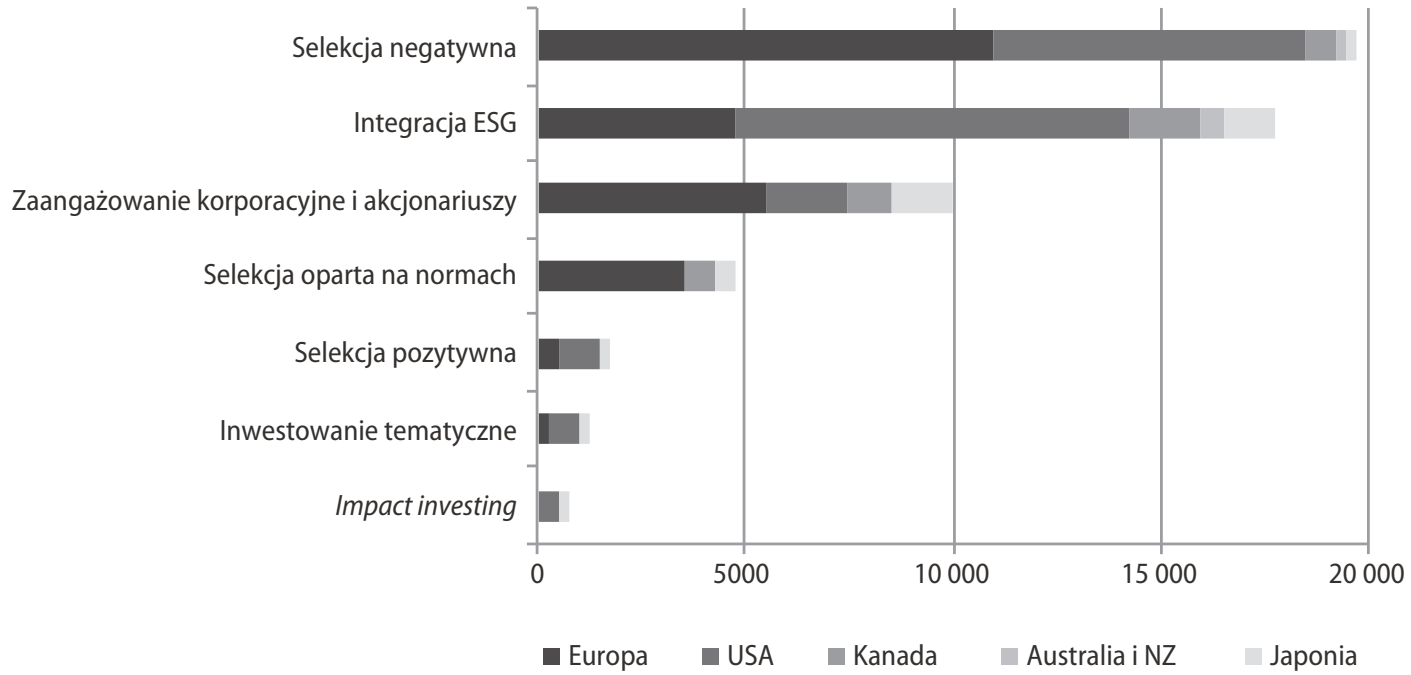

Źródło: opracowanie własne na podstawie [GSIA, 2018].

Podejście oparte na selekcji negatywnej ewoluowało w latach 90. XX w. w kierunku bardziej złożonych strategii, takich jak integracja - drugie najczęściej wykorzystywane podejścia do SRI. Polega ona na włączeniu czynników ESG do procesu inwestycyjnego, np. przypisaniu im konkretnej wagi (np. 10-20\%) w procesie selekcji spółek/funduszy lub - idąc znacznie dalej - oszacowanie wpływu tych elementów na wycenę spółki (np. w formie zdyskontowanych przepływów pieniężnych). W tym przypadku mamy do czynienia z bardzo szerokim spektrum stosowanych metod, dlatego dokonanie rzetelnej analizy powinno być przeprowadzane na poziomie pojedynczych strategii.

9 Przykładowo, powstrzymanie się od inwestowania w sektory producentów broni, paliw kopalnych, czy tytoniowy jest proste i jednocześnie wysyła jednoznaczny, oparty na konkretnych wartościach, komunikat do odbiorców. 
Kolejne dwa szeroko wykorzystywane podejścia do SRI to selekcja oparta na normach oraz zaangażowanie korporacyjne i akcjonariuszy. Pierwsze z nich można porównać do selekcji negatywnej, jednak opartej na międzynarodowych standardach. W praktyce zarządzający mogą wykorzystywać screening oparty na zgodności z regulacjami ONZ, OECD, ILO, UNICEF i innych uznanych podmiotów. Ta analiza ma prowadzić zazwyczaj do wykluczenia danej spółki/kraju ze spektrum inwestycyjnego bądź też zmiany udziału w portfelu (np. doważając liderów w implementacji standardów, a nie doważając tych o mniejszej aktywności). Zaangażowanie korporacyjne i akcjonariuszy jest dużo szersze oraz trudniejsze w analizie, gdyż może obejmować takie aktywności, jak np. głosowanie w sprawach związanych z ESG zgodnie z ustalonymi standardami, prezentowanie własnych inicjatyw i oczekiwań (zarówno przez akcjonariuszy, jak i pracowników), dzielenie się najlepszymi praktykami itp.

Co ciekawe, najrzadziej wykorzystywanym sposobem inwestowania odpowiedzialnego jest tzw. impact investing ${ }^{10}$ i sytuacja ta trwa od co najmniej 10 lat [Cibor, Muzińska, 2011]. Większość inwestycji tego typu jest prowadzona w formule niepublicznej, z długim horyzontem inwestycyjnym (np. fundusze PE i VC), co zawęża grono zainteresowanych. Sposób implementacji czynników ESG do procesu inwestycyjnego jest bardziej skomplikowany niż w metodach opartych na selekcji czy integracji. Podczas gdy zastosowanie strategii SRI $\mathrm{w}$ tradycyjnym funduszu akcji mogłoby teoretycznie nastąpić w ciągu kilku dni (np. sprzedaż wszystkich spółek z negatywnie ocenianych sektorów), stworzenie od podstaw strategii osiągnięcia konkretnego wpływu na społeczeństwo lub środowisko jest zadaniem dalece bardziej złożonym. Co również nie jest bez znaczenia, głównym celem inwestowania zaangażowanego często jest nie tyle zysk finansowy, ile zamierzony zysk społeczny.

Rysunek 2. Aktywa SRI i ich dynamika według wykorzystywanej strategii (w mld USD)

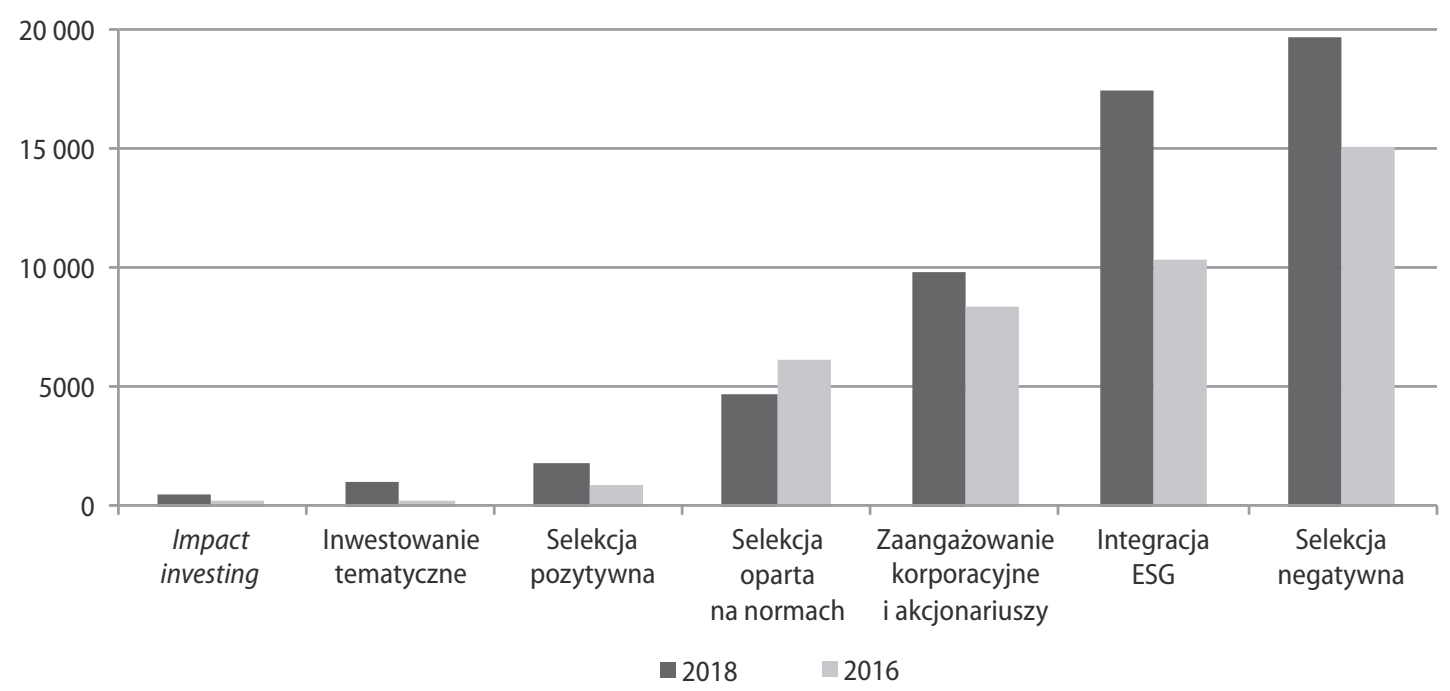

Źródło: opracowanie własne na podstawie [GSIA 2018].

10 Pojęcie to można tłumaczyć jako inwestowanie zaangażowane społecznie. 
Aktywa zarządzane zgodnie z jedną z opisanych powyżej strategii rosną w ostatnich latach w bardzo szybkim tempie, co widać na rysunku 2 i w tabeli 3. Wśród strategii o dużych aktywach uwagę zwraca dynamiczny wzrost wykorzystania integracji ESG, która w ostatnich latach zyskuje wyraźnie na znaczeniu. Spadek aktywów pod zarządzaniem obserwowaliśmy w okresie 2016-2018 wyłącznie wśród strategii opartych na normach.

Analizując strukturę inwestorów, można zauważyć, że rynek SRI jest zdominowany przez inwestorów instytucjonalnych (takich jak np. fundusze emerytalne czy ubezpieczyciele) - ich udział w 2018 r. wyniósł ok. 75\%. Inwestorzy detaliczni wykazują jednak coraz większe zainteresowanie tematem SRI, a ich udział w ostatnich latach stale rośnie z ok. 11\% w 2012 r. do ok. 25\% w 2018 r. [GSIA, 2018].

Tabela 3. Aktywa SRI i ich dynamika według wykorzystywanej strategii (w mld USD)

\begin{tabular}{|l|c|c|c|c|c|c|c|}
\hline $\begin{array}{l}\text { Latalsposoby } \\
\text { inwestowania }\end{array}$ & $\begin{array}{c}\text { Impact } \\
\text { investing }\end{array}$ & $\begin{array}{c}\text { Inwestowanie } \\
\text { tematyczne }\end{array}$ & $\begin{array}{c}\text { Selekcja } \\
\text { pozytywna }\end{array}$ & $\begin{array}{c}\text { Selekcja oparta } \\
\text { na normach }\end{array}$ & $\begin{array}{c}\text { Zaangażowanie } \\
\text { korporacyjne } \\
\text { i akcjonariuszy }\end{array}$ & $\begin{array}{c}\text { Integracja } \\
\text { ESG }\end{array}$ & $\begin{array}{c}\text { Selekcja } \\
\text { negatywna }\end{array}$ \\
\hline 2018 & 444,26 & 1017,66 & 1841,87 & 4679,44 & 9834,59 & 17543,81 & 19770,96 \\
\hline 2016 & 248,47 & 276,17 & 818,01 & 6195,40 & 8385,17 & 10353,20 & 15063,57 \\
\hline$\Delta 2016-2018$ & $79 \%$ & $269 \%$ & $125 \%$ & $-24 \%$ & $17 \%$ & $69 \%$ & $31 \%$ \\
\hline CAGR & $33,70 \%$ & $92 \%$ & $50,10 \%$ & $-13,10 \%$ & $8,30 \%$ & $30,20 \%$ & $14,60 \%$ \\
\hline
\end{tabular}

Źródło: Opracowanie własne na podstawie [GSIA, 2018].

\subsection{Inwestowanie zrównoważone w praktyce}

Dynamiczny rozwój rynku finansowego sprawił, że inwestowanie zrównoważone jest coraz bardziej powszechne $\mathrm{w}$ formie m.in. otwartych funduszy inwestycyjnych oraz funduszy PE czy inwestycji bezpośrednich w pojedyncze projekty. Najbardziej popularną formą inwestycji pozostają jednak fundusze otwarte, co wynika m.in. z niskich progów wpłat, sposobu ich dystrybucji oraz szerokiej oferty. Pierwsze z funduszy otwartych miały charakter aktywny i do dziś tego typu strategie zgromadziły największe aktywa, co widać w tabeli 4 na przykładzie rynku amerykańskiego [Hale, 2018].

Podobnie jak w przypadku tradycyjnych sposobów inwestowania w akcje czy obligacje, również w obszarze inwestowania zrównoważonego obserwujemy silny wzrost zainteresowania funduszami pasywnymi, głównie w formie handlowanych na giełdach ETF ${ }^{11}$ (rysunek 3). Szacuje się, że tego typu strategie stanowią ok. 30\% rynku amerykańskiego, ale w ostatnich latach ich udział rośnie [Hale, 2018].

11 ETF (Exchange Traded Fund) - otwarty fundusz inwestycyjny, którego co najmniej jedna jednostka lub klasa jest przedmiotem obrotu giełdowego. 
Tabela 4. Największe fundusze zrównoważone w USA (wraz z kategorią, datą rozpoczęcia działalności i wartością aktywów będących w zarządzaniu)

\begin{tabular}{|l|l|c|l|}
\hline \multicolumn{1}{|c|}{ Name } & \multicolumn{1}{|c|}{ Morningstar Category } & Inception Date & \multicolumn{1}{c|}{ AUM-2017-12 } \\
\hline Parnassus Core Equity Inv & Large Blend & $8 / 31 / 92$ & 16.157 .259 .603 \\
\hline Parnassus Endeavor Inv & Large Blend & $4 / 29 / 05$ & 5.210 .147 .475 \\
\hline JPMorgan Emerging Markets Equity A & Diversified Emerging Mkts & $9 / 28 / 01$ & 4.806 .092 .495 \\
\hline Vanguard FTSE Social Index Inv & Large Blend & $5 / 31 / 00$ & 3.905 .146 .250 \\
\hline TIAA-CREF Social Choice Eq Instl & Large Blend & $7 / 1 / 99$ & 3.059 .067 .271 \\
\hline Hartford Schroders Emerging Mkts Eq I & Diversified Emerging Mkts & $3 / 31 / 06$ & 2.867 .186 .636 \\
\hline Parnassus Mid-Cap & Mid-Cap Blend & $4 / 29 / 05$ & 2.802 .512 .071 \\
\hline Neuberger Berman Socially Rspns Inv & Large Growth & $3 / 16 / 94$ & 2.357 .059 .897 \\
\hline Calvert Equity A & Large Growth & $8 / 24 / 87$ & 2.207 .510 .449 \\
\hline CRA Qualified Investment CRA & Intermediate Government & $8 / 30 / 99$ & 2.131 .921 .276 \\
\hline
\end{tabular}

Źródło: [Hale, 2018].

Rysunek 3. Nowo otwierane fundusze zrównoważone w USA - fundusze notowane na giełdzie (Exchange Traded) i nienotowane fundusze otwarte (Open End)

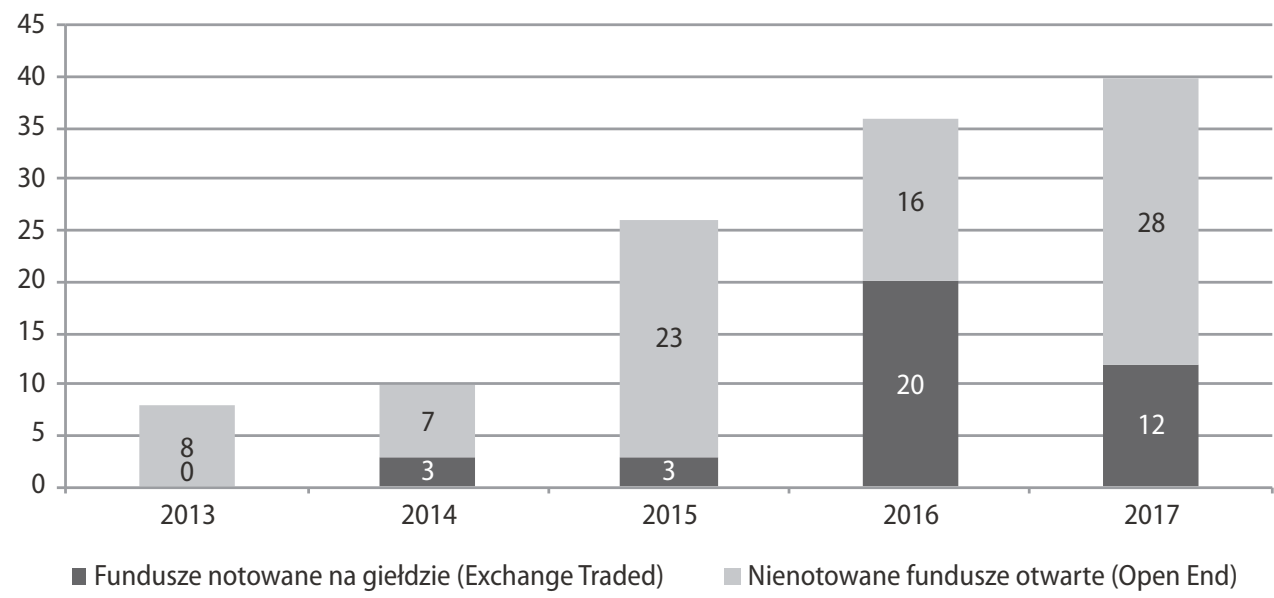

Źródło: opracowanie własne na podstawie [Hale, 2018].

Choć większość z wprowadzanych strategii to nowe fundusze, zauważalny jest także trend, który polega na uwzględnianiu kryteriów zrównoważonego inwestowania w już istniejących strategiach, za czym czasem idzie również zmiana nazwy [Hale, 2018]. Wyzwaniem dla inwestorów jest sposób oceny, czy tego typu zmiana jest zabiegiem marketingowym (odpowiadającym na zapotrzebowanie rynku), czy wręcz przeciwnie - ważnym elementem procesu inwestycyjnego [J.P. Morgan, 2018] ${ }^{12}$. Nawet ogólny zapis w statucie funduszu sprawia,

12 Przykładowo, wspomniany w tabeli 4 fundusz JP Morgan Emerging Markets Equity w suplemencie do prospektu (z 21.11.2017) umieścił następujące odniesienie do czynników ESG: „Analitycy starają się oceniać czynniki ryzyka związane z kwestiami środowiskowymi, społecznymi i z ładem korporacyjnym”. 
że analityk może uczynić z czynników ESG ryzyka ważną część procesu inwestycyjnego, a równie dobrze nie przywiązywać do nich zbyt dużej wagi. Określenie rzeczywistości nie jest więc łatwe, nawet dla osób zajmujących się zawodowo oceną funduszy.

Pewnym wsparciem w selekcji funduszy inwestujących z godnie z SRI może być korzystanie z serwisów branżowych. Przykładowo, duże zainteresowanie inwestowaniem odpowiedzialnym skłoniło spółkę Morningstar ${ }^{13}$ do wprowadzenia w 2016 r. narzędzia, które pozwala ocenić fundusze pod kątem kryteriów inwestowania zrównoważonego na tle swojej konkurencji [Hale, 2017]. Morningstar Sustanability Rating jest miarą, która określa, w jakim stopniu spółki znajdujące się w portfelu danego funduszu zarządzają ryzykiem związanym z czynnikami ESG. Wynikiem analizy jest przyznanie funduszom publicznie dostępnego ratingu od 0 do 5 globusów (więcej globusów to wyższa ocena). Przykładem płatnego narzędzia służącego ocenie funduszy jest MSCI ESG Fund Metrics, pozwalający przeanalizować pod kątem ESG ok. 23000 strategii [https://www.msci.com/esg-fund-metrics].

W przypadku funduszy pasywnych, kryteria brane pod uwagę w tworzeniu indeksów są bardziej przejrzyste niż wśród strategii aktywnych. ETF-y opierają się na uznanych indeksach (np. MSCI, FTSE), których metodologia jest szeroko dostępna ${ }^{14}$. Liderem branży funduszy pasywnych jest iShares, oferujący 27 funduszy pasywnych (tabela 5). Większość z nich opiera się na integracji ESG, ale dostępne są także ETF-y skupiające się na konkretnych sektorach oraz wykorzystujące negatywną selekcję ${ }^{15}$. Również najwięksi konkurenci iShares planują wprowadzenie produktów opartych na idei zrównoważonego inwestowania [Stein, 2018] i można oczekiwać, że rynek ten będzie nadal dynamicznie rósł.

Sposoby oceny spółek pod kątem ESG różnią się pomiędzy liderami branży i nie został jak dotąd wypracowany jeden uznany standard oceny. Widać to doskonale na rysunku 4 - korelacja pomiędzy ocenami środowiskowymi, społecznymi lub dotyczącymi ładu korporacyjnego badanych spółek, sporządzanymi przez trzech wykorzystywanych dostawców danych, jest stosunkowo niska ${ }^{16}$.

13 Morningstar jest niezależną spółką zajmującą się zbieraniem danych i badaniami nt. rynku funduszy inwestycyjnych, ETF-ów i innych instrumentów finansowych. Jest uznawana za wiodący podmiot oceniający jakość zarządzania funduszami.

14 Nie oznacza to jednak, że analiza stosowanego podejścia jest prosta dla przeciętnego inwestora. Każdy z indeksów opiera się na innych metodach ratingu pojedynczych spółek lub papierów wartościowych, przyjmuje różne wagi dla czynników środowiskowych, społecznych, czy związanych z ładem korporacyjnym, a także może przyjmować różne warianty pomiędzy krajami czy sektorami. Najbardziej istotne dla inwestora może być jednak sprawdzenie, czy indeks ma na celu ocenę relatywną, czy nie. Przeanalizujmy przykładowo spółkę zajmującą się wydobyciem ropy. Załóżmy, że jest to podmiot, który wyróżnia się na tle konkurencji pod względem zastosowania nowoczesnych metod wydobycia i dzięki temu ogranicza swój negatywny wpływ na środowisko. W indeksie, który analizuje przedsiębiorstwa relatywnie, tego typu spółka mogłaby się znaleźć jako lider swojej branży (prawdopodobnie z wysokim ratingiem). W indeksie, który analizuje spółki w kategoriach absolutnych (tzn. ich rzeczywistego wpływu na środowisko), tego typu podmiot nigdy się nie znajdzie.

15 Przykładowo ETF oparty na uruchomionym w 1990 r. MSCI KLD 400 Social Indeks (jeden z pierwszych indeksów SRI w historii).

16 Ten argument jest często wykorzystywany przez przedstawicieli aktywnych funduszy do podważania sensowności inwestowania pasywnego. 
Tabela 5. Wybrane fundusze pasywne w ofercie iShares

\begin{tabular}{|l|l|c|l|l|c|}
\hline $\begin{array}{c}\text { Ticker } \\
\text { (skrócona } \\
\text { nazwa) }\end{array}$ & \multicolumn{1}{|c|}{ Nazwa } & $\begin{array}{c}\text { Punktacja } \\
\text { ESG } \\
\text { (percentyl) }\end{array}$ & $\begin{array}{r}\text { Typ funduszu } \\
\text { (liczba funduszy w grupie) }\end{array}$ & $\begin{array}{c}\text { Procent aktywów } \\
\text { pokrytych przez } \\
\text { badanie MDCI ESG }\end{array}$ \\
\hline \multicolumn{5}{|c|}{ ZAPOBIEGANIE - unikanie inwestycji w przedsiębiorstwa z kontrowersyjnych sektorów } \\
\hline DSI & iShares MSCI KLD 400 Social ETF & 98 & Equity US (2714) & 98,9 \\
\hline \multicolumn{1}{|c|}{ PROMOWANIE - inwestowanie w przedsiębiorstwa, których praktyki są wysoko oceniane według standardów ESG } \\
\hline SUSA & iShares MSCI USA ESG Select ETF & 100 & Equity US (2714) & 99,4 \\
\hline ESGU & iShares MSCI USA ESG Optimized ETF & 98 & Equity US (2714) & 99,1 \\
\hline ESGD & iShares MSCI EAFE Optimized ETF & 99 & Equity Global ex-US (764) & 99,9 \\
\hline ESGE & iShares MSCI EM ESG Optimized ETF & 97 & $\begin{array}{l}\text { Equity Emerging Markets Global } \\
\text { (841) }\end{array}$ & 99,2 \\
\hline SUSC & iShares ESG USD Corporate Bond ETF & 99 & Bond USD Medium Term (151) & 90,4 \\
\hline SUSB & $\begin{array}{l}\text { iShares ESG USD 1-5 Year USD } \\
\text { Corporate BOND ETF }\end{array}$ & 100 & Bond USD Medium Term (151) & 99,4 \\
\hline ESML & $\begin{array}{l}\text { iShares MSCI USA Small-Cap ESG } \\
\text { Opptimized ETF }\end{array}$ & $\mathrm{n} / \mathrm{d}$ & $\mathrm{n} / \mathrm{a}$ & $\mathrm{n}$ \\
\hline CEL - inwestowanie w przedsiębiorstwa, których produkty i są usługi ukierunkowane na mierzalny wpływ społeczny \\
\hline ICLN
\end{tabular}

Źródło: [https://www.ishares.com/uk/individual/en/themes/sustainable-investing].

Rysunek 4. Korelacja pomiędzy ocenami spółek pod katem ESG przez różnych dostawców danych (ocena środowiskowa, społeczna lub dotycząca ładu korporacyjnego)

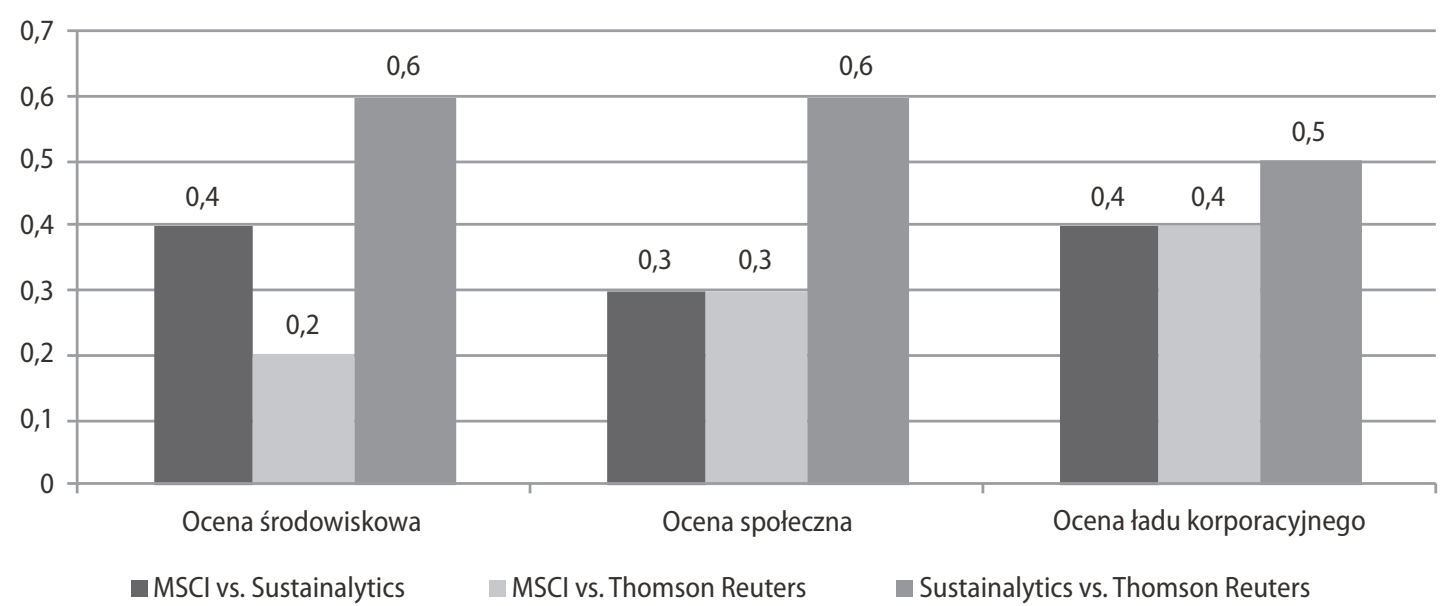

Źródło: opracowanie własne na podstawie [https://www.schroders.com/en/insights/economics/esg-in-passive-let-the-buyer-beware/]. 
Inwestowanie zrównoważone zdaje się też stanowić coraz ważniejszą część rynku niepublicznego. Integracja czynników ESG do procesu inwestycyjnego przez branżę PE trwa już od wielu lat. Choć analiza rynku PE jest trudniejsza z uwagi na mniejszą przejrzystość branży i brak przekrojowych opracowań poświęconych inwestowaniu zrównoważonemu, trudno nie odnieść wrażenia, że tendencje są analogiczne do tych obserwowanych na rynkach publicznych ${ }^{17}$. Już teraz widać wiele przykładów na to, że fundusze inwestujące w sposób tradycyjny stosują zasady zrównoważonego inwestowania. Poza tym powstaje coraz więcej funduszy dedykowanych wyłącznie tego typu inwestycjom. Inwestorzy mogą też zauważyć coraz więcej przykładów firm zarządzających, które tworzą polityki odpowiedzialnego inwestowania i publicznie dzielą się raportami ze swojej działalności w tym obszarze. Przykładów tego typu dobrych praktyk nie trzeba szukać daleko - Innova Capital (znany fundusz PE działający w Europie Centralnej) od kilku lat uwzględnia czynniki ESG na wszystkich etapach cyklu inwestycyjnego, a od 2014 r. publikuje roczne raporty z tego obszaru [https:// www.innovacap.com/pl/strategia-/odpowiedzialne-inwestowanie/].

Rysunek 5. Liczba funduszy/produktów impact według formy inwestycji oraz rynku

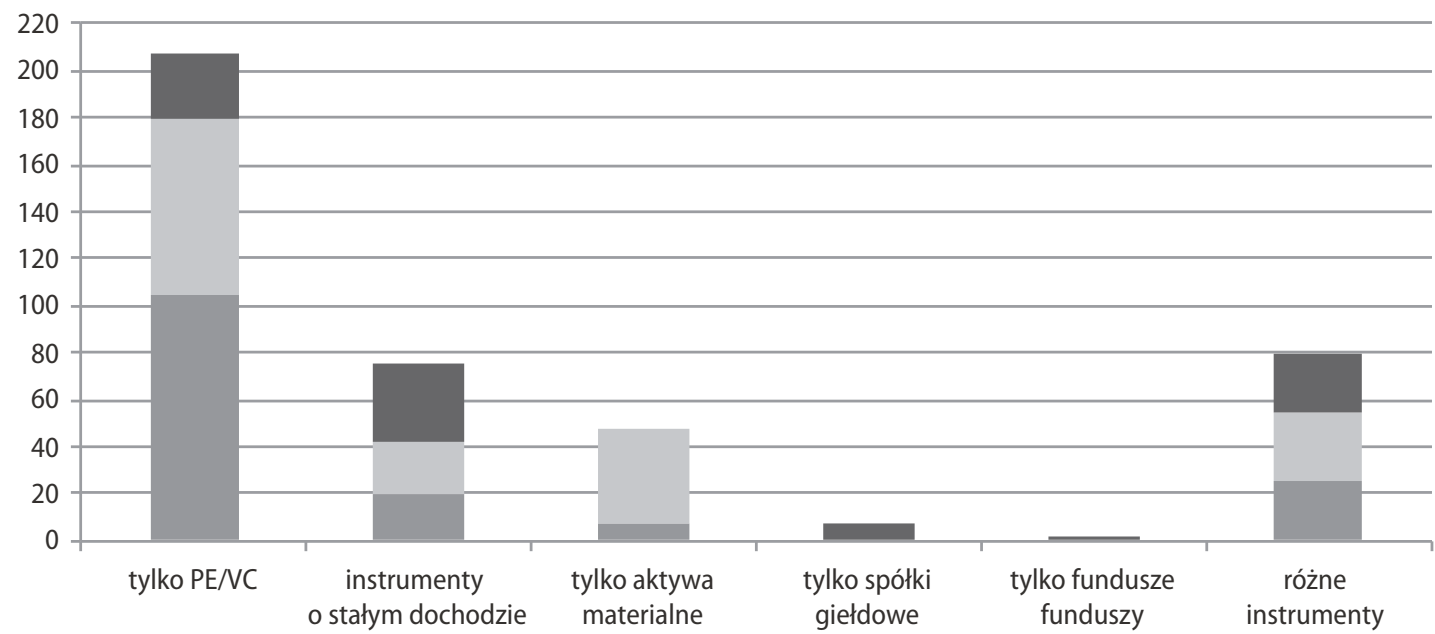

- Koncentracja na rynkach rozwijających się $\quad$ Koncentracja na rynkach rozwiniętych $\quad$ Ekspozycja globalna

Źródło: opracowanie własne na podstawie [ImpactBase].

Rynek niepubliczny to jeden z niewielu efektywnych sposobów prowadzenia działalności przez fundusze typu impact. Według danych ImpactBase ${ }^{18}$ (rysunek 5) najwięcej z nich można znaleźć wśród grupy funduszy PE, których połowa skupia się na rynkach wschodzących, co wydaje się intuicyjne, bo w tych obszarach działalność tego typu jest najbardziej

\footnotetext{
17 Przykładowo, z badań wśród przedstawicieli branży PE wynika, że czynniki ESG będą w kolejnych latach coraz ważniejszym elementem procesu inwestycyjnego (tak twierdzi 78\% ankietowanych w raporcie Intertrust 2017).

18 Globalna baza on-line, która służy jako narzędzie wyszukiwania funduszy typu impact.
} 
potrzebna. Dużym obszarem jest grupa produktów dłużnych oraz aktywów trwałych (ang. real assets). Z uwagi na minimalny poziom inwestycji produkty tego typu są przeważnie przeznaczone dla inwestorów dysponujących większym kapitałem $\left(\mathrm{HNWI}^{19}\right.$ oraz $\left.\mathrm{UHNWI}^{20}\right)$.

\section{Inwestowanie zrównoważone a stopy zwrotu}

\subsection{Oczekiwania inwestorów od inwestycji zrównoważonych}

Przed analizą wyników inwestowania w spółki SRI warto odpowiedzieć na pytanie, czy dla inwestora kluczowe znaczenie ma wyłącznie stopa zwrotu, czy też istotna jest sama świadomość pozytywnego wykorzystania środków finansowych. Przeważnie przy zastosowaniu drugiego kryterium wystarczy, że stopa zwrotu z inwestycji będzie nieujemna. Czy inwestorzy są gotowi ponosić dodatkowe koszty zrównoważonego rozwoju, o ile takie w ogóle występują? Zgodnie z wynikami badań Nielsena (rysunek 6) konsumenci są gotowi płacić więcej za te produkty, które pozytywnie oddziałują na środowisko naturalne czy społeczeństwo. Skoro społeczeństwo jest gotowe ponosić dodatkowy koszt związany z konsumpcją zgodną z zasadami zrównoważonego rozwoju, to powinno kreować także popyt na takie inwestycje.

Rysunek 6. Czynniki wpływające na wybór przez konsumentów produktów spełniających kryteria CSR/SRI (globalni respondenci vs ci skłonni zapłacić więcej) (w \%)

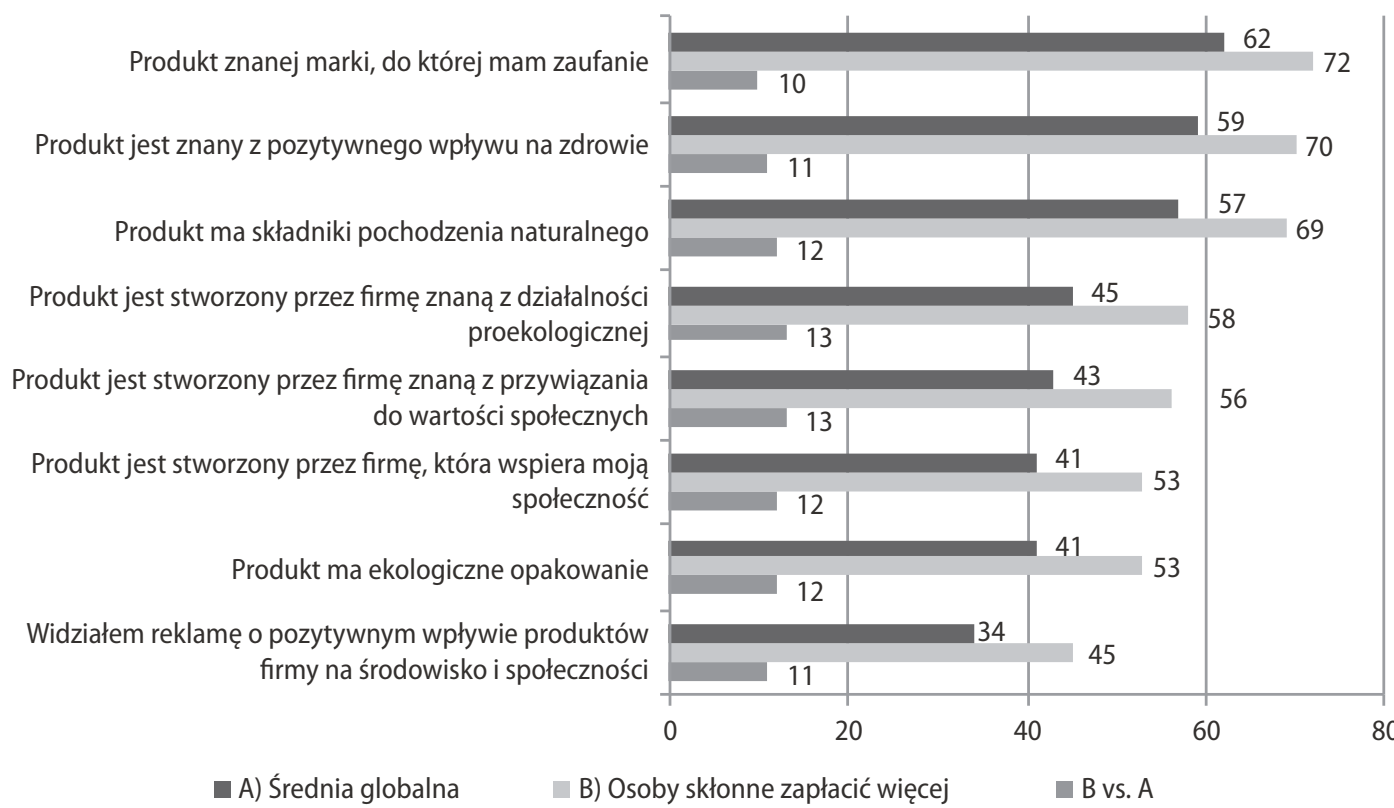

Źródło: opracowanie własne na podstawie [Nielsen, 2015].

19 High-Net-Worth Individual - osoba posiadająca aktywa o wartości min. 1 mln USD.

20 Ultra-High-Net-Worth Individual - osoba posiadająca aktywa o wartości min. $30 \mathrm{mln}$ USD. 
Zgodnie z badaniami Morgan Stanley głównym czynnikiem wspierającym wprowadzenie zasad zarządzania majątkiem zgodnie z wytycznymi ESG jest właśnie popyt klientów (rysunek 7). Sam wynik inwestycji ma mniejsze znaczenie, jeśli cele klientów można realizować, uwzględniając wpływ poszczególnych elementów na otoczenie. Oczywiście nie można uznać, że stopa zwrotu z inwestycji społecznie odpowiedzialnych może bardzo negatywnie odbiegać od rynkowej stopy zwrotu, ale należy przyjąć, że nie może być ona znacząco niższa.

Rysunek 7. Czynniki kreujące popyt na uwzględnienie czynników związanych z inwestowaniem zrównoważonym wśród zarządzających aktywami (wykres pokazuje, ile procent respondentów uznało dany czynnik za najważniejszy)

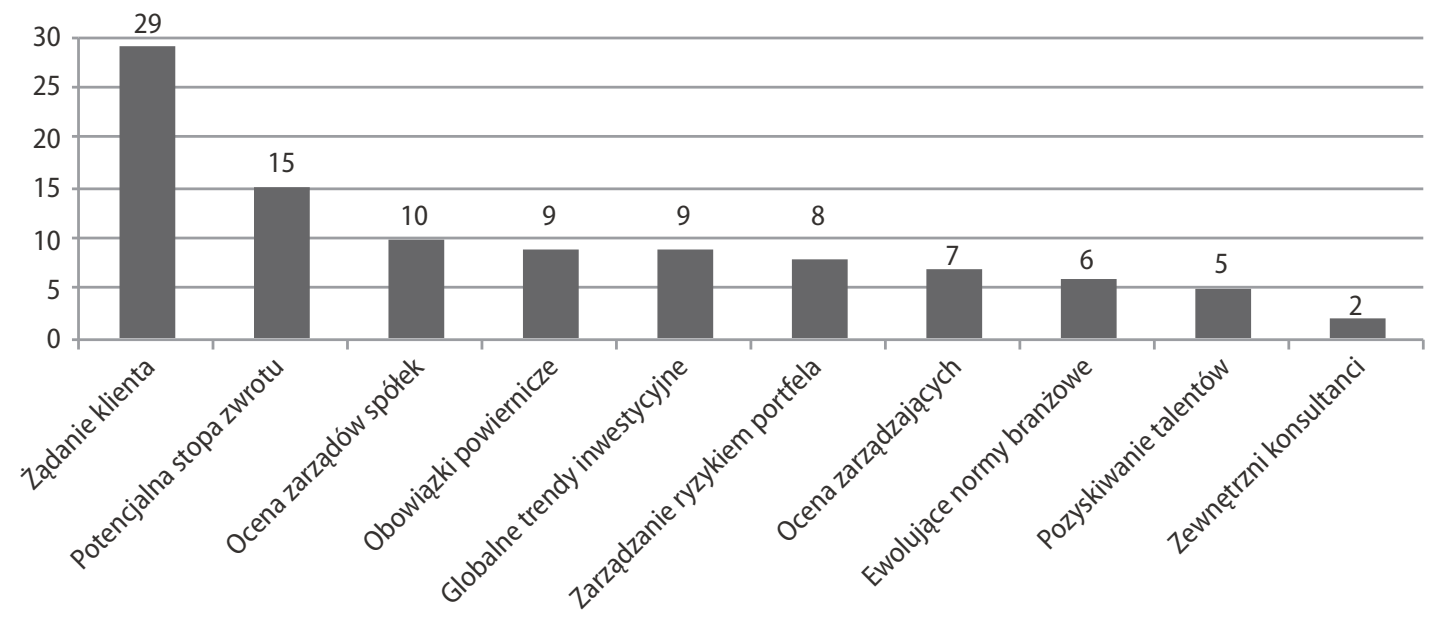

Źródło: opracowanie własne na podstawie [Morgan Stanley, 2016, s. 8].

\subsection{Wpływ czynników ESG na wyniki finansowe spółek}

Jednym z podstawowym pytań, jakie należy zadać w kontekście inwestycji społecznie odpowiedzialnych, jest to, czy istnieje zależność pomiędzy szeroko rozumianymi czynnikami ESG a wynikami finansowymi spółek i - idąc dalej - stopami zwrotu ze strategii inwestujących zgodnie z metodologią SRI. Temat ten zajmuje badaczy i inwestorów od lat 70. XX w., a od tego czasu opublikowano ponad 2000 badań empirycznych, w różny sposób ujmujących zagadnienie [Friede, Busch, Bassen, 2015]. Literatura przeczy powszechnemu mitowi, że wybierając spółki przykładające większą uwagę do czynników społecznych, środowiskowych czy związanych z ładem korporacyjnym, niejako „poświęcamy” część potencjalnej stopy zwrotu na rzecz realizacji tych celów [Friede, Busch, Bassen, 2015].

Ponad $90 \%$ badań dotyczących inwestycji społecznie odpowiedzialnych nie wskazało negatywnego wpływu stosowania kryteriów ESG na wyniki finansowe spółek. Co więcej, większość badań dowiodło, że implementacja kryteriów ESG w działalności spółki przynosi wymierne korzyści finansowe, co zobrazowano na rysunku 8 [Friede, Busch, Bassen, 2015]. 
Przedsiębiorstwa wysoko oceniane pod kątem ESG osiągają średnio lepsze i bardziej stabilne wyniki finansowe niż pozostałe spółki. Jest to rezultatem m.in. niższego kosztu kapitału lub wyższych ratingów kredytowych [Bauer, Hann, 2010; Attig, 2013]. Cena za zaniedbanie czynników pozafinansowych w przedsiębiorstwie potrafi być wysoka - badania wykazują, że spółki nieefektywne w zarządzaniu ryzykiem środowiskowym miały średnio o 20\% wyższy koszt zadłużenia [Chava, 2011] i zazwyczaj wyższy koszt kapitału własnego [El Ghoul i in., 2016].

Rysunek 8. Wpływ czynników ESG na osiągane wyniki finansowe spółek w zależności od przyjętej metodologii badania ( $w \%)$

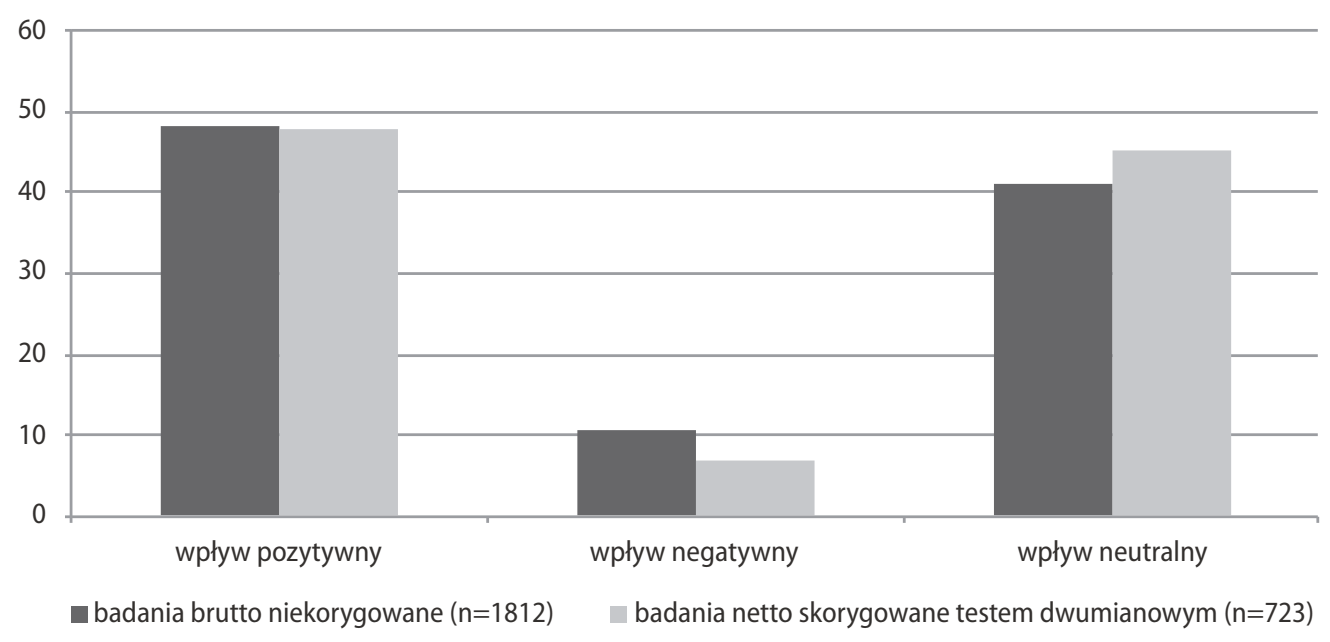

Źródło: opracowanie własne na podstawie [Friede, Busch, Bassen, 2015, s. 210-233].

\subsection{Wpływ czynników ESG na stopy zwrotu z akcji i funduszy}

Analiza zależności między czynnikami ESG a cenami akcji nie wykazuje, że inwestowanie zrównoważone generuje dodatkowy „koszt”. Porównując wyniki indeksów akcji do ich odpowiedników skonstruowanych na podstawie kryteriów ESG, możemy zauważyć, że stopy zwrotu i zmienność są zbliżone (tabela 6). Fundusze pasywne oparte na indeksach ESG cechowały się podobną relacją zysku do ryzyka co ETF-y oparte na szerokich indeksach.

Analiza stóp zwrotu funduszy aktywnych inwestujących w sposób zrównoważony przynosi podobne wnioski - trudno stwierdzić, aby cechowały się one systematycznie gorszymi wynikami. Literatura wskazuje, że wyniki te są porównywalne z konwencjonalnymi funduszami [Morningstar, 2016]. Występuje tu efekt „liderów” - spółki, które wyróżniają się pod kątem czynników ESG, osiągają na tle konkurencji średnio lepsze wyniki. Wnioski badań Morningstar są spójne zarówno wśród funduszy akcyjnych, jak i obligacyjnych [Morningstar, 2018]. Badania wskazują też, że uwzględnianie czynników ESG może nie tyle wpływać na potencjał wzrostowy, ile zmniejszać zmienność i głębokość spadków w momentach 
nerwowości na rynkach, co z kolei może być ważnym czynnikiem przy budowie portfela inwestycyjnego [J.P. Morgan, 2016].

Tabela 6. Wpływ czynników ESG na osiągane wyniki finansowe

\begin{tabular}{|l|c|c|c|c|c|c|}
\hline \multirow{2}{*}{ Rodzaje aktywów } & \multicolumn{2}{c|}{ USA } & \multicolumn{2}{c|}{ Świat poza USA } & \multicolumn{2}{c|}{ Rynki wschodzące } \\
\cline { 2 - 7 } & Tradycyjne & ESG & Tradycyjne & ESG & Tradycyjne & ESG \\
\hline Uroczniona stopa zwrotu & $15,8 \%$ & $15,8 \%$ & $10,5 \%$ & $11,1 \%$ & $7,8 \%$ & $9,1 \%$ \\
\hline Zmienność & $9,5 \%$ & $9,6 \%$ & $11,4 \%$ & $11,6 \%$ & $14,4 \%$ & $14,3 \%$ \\
\hline Współczynnik Sharpe'a & 1,62 & 1,60 & 0,88 & 0,92 & 0,51 & 0,61 \\
\hline Max. spadek (ang. drawdown) & $-13,9 \%$ & $-13,8 \%$ & $-23,3 \%$ & $-22,6 \%$ & $-35,2 \%$ & $-33,0 \%$ \\
\hline Cena/Zysk (P/E) & 19,4 & 19,5 & 17,2 & 17,1 & 13,3 & 13,7 \\
\hline Stopa dywidendy & $2,1 \%$ & $2,1 \%$ & $3,2 \%$ & $3,2 \%$ & $2,7 \%$ & $2,8 \%$ \\
\hline Liczba spółek & 620 & 293 & 1011 & 419 & 831 & 288 \\
\hline Punktacja ESG & 5,2 & 6,6 & 6,5 & 7,9 & 4,4 & 6,2 \\
\hline
\end{tabular}

Źródło: opracowanie własne na podstawie [Blackrock, 2018].

Rysunek 9. Oczekiwania inwestorów co do wyników osiąganych przez fundusze typu impact (w \%)

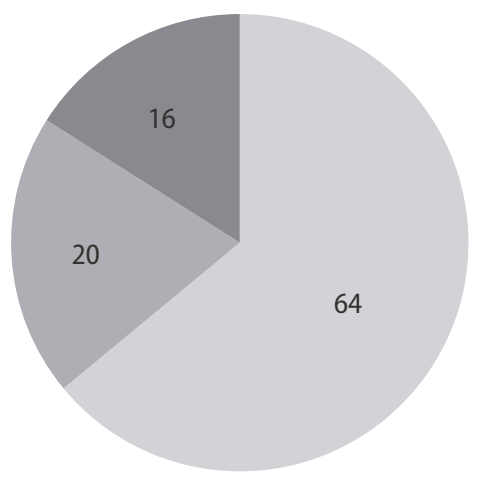

$$
\begin{aligned}
& \text { rynkowe stopy zwrotu dopasowane do odpowiedniego poziomu ryzyka } \\
& \text { stopy zwrotu poniżej rynkowej lub bliskie stopie rynkowej } \\
& \text { stopy zwrotu poniżej rynkowej, nakierowane na zachowanie kapitału }
\end{aligned}
$$

Źródło: opracowanie własne na podstawie [GIIN Research Team, 2018].

W przypadku funduszy inwestujących zgodnie z filozofią impact, stopa zwrotu często nie jest głównym kryterium branym pod uwagę przez inwestorów. Celem tego podejścia jest wykreowanie pozytywnych zmian społecznych lub środowiskowych, dlatego osiągane wyniki mogą być sprawą drugorzędną. Według badań Global Impact Investing Network wśród tej grupy inwestorów ok. 1/3 spodziewa się stopy zwrotu niższej niż rynkowa (rysunek 9). Pozostali liczą się z wynikami zbliżonymi do średniej, uwzględniając podjęte ryzyko. 
Fundusze typu impact częściej pozytywnie zaskakują niż rozczarowują pod kątem osiąganych stóp zwrotu. Na poziomie finansowym w ok. 15\% przypadków wyniki są lepsze niż oczekiwania (ok. 9\% rozczarowuje), zaś pod kątem wpływu na społeczeństwo/środowisko te statystki są jeszcze lepsze (15\% vs 3\%) [GIIN Research Team, 2018].

\section{Inwestowanie zrównoważone w Polsce}

\subsection{Uwarunkowania rozwoju inwestowania zrównoważonego w Polsce}

Warto spojrzeć na inwestowanie zrównoważone przez pryzmat historii Polski i transformacji ustrojowej. Obecnie największym kapitałem dysponuje pokolenie w wieku 45-54 lat [NBP, 2017], które w życie zawodowe wchodziło na przełomie lat 70. i 80. Był to czas robotniczych protestów, „Solidarności” i stanu wojennego [Hysa, 2016], a ludzie ci szczyt aktywności zawodowej osiągnęli już w gospodarce wolnorynkowej. Z kolei osoby urodzone w okresie 1965-1980 wchodziły w dorosłe życie w trudnym czasie restrukturyzacji gospodarki [Hysa, 2016]. Lata 90. XX w. to okres wysokiej inflacji i bezrobocia, co potęgowało u pracowników brak poczucia stabilizacji. Jest to całkowicie odmienny obraz doświadczeń w porównaniu z okresem dynamicznego, na ogół pozbawionego rewolucyjnych zmian ustrojowych rozwoju gospodarek światowych w latach 1945-2000.

Patrząc na obraz wskazanej powyżej zmiany pokoleniowej, należałoby się zastanowić, jakie może mieć ona przełożenie na inwestowanie zrównoważone. Należy wysunąć tezę, że w Polsce nie wykształciła się jeszcze potrzeba inwestowania zrównoważonego, lecz będzie ona rosnąć wraz z transferem kapitału do młodszych generacji. Choć poziom tej świadomości trudno zmierzyć, autorzy przyjęli założenie, że jej rozwój będzie równoległy do zmian świadomości ekologicznej, co staje się powoli widoczne. W latach 1990-2000 „Działaniom instytucjonalnym towarzyszyła negatywna ocena społeczna i nieufność” [Kłos, 2015, s. 38].

Kolejne 20 lat przyniosło istotne zmiany. „Stosunkowo wysoki poziom wrażliwości na środowisko zauważalny jest w grupie osób w wieku 39-45 lat, natomiast osoby w wieku 18-24 lata charakteryzuje najniższy poziom postaw proekologicznych przy zdecydowanie wyższym poziomie wiedzy ekologicznej" [Kłos, 2015, s. 39]. Oznaczałoby to, że wrażliwość inwestorów na ekologię rośnie wraz z wiekiem. Wspierane jest to faktem, że „zdecydowanie wzrasta wśród badanych liczba osób, dla których przyjęcie środowiska za niezbywalną wartość stanowi motyw do podejmowania pozytywnej aktywności na rzecz przyrody” [Kłos, 2015, s. 39].

Zgodnie z badaniem „Moralność finansowa Polaków” [KPF, 2017], źródłem niskiej dynamiki w zakresie inwestycji zrównoważonych w Polsce może być niski poziom zaufania do instytucji finansowych ogółem - wątpliwości w tym zakresie wyraża 84\% ankietowanych. Zaufanie to przekłada się na procesy inwestycyjne gospodarstw domowych. Od dłuższego czasu obserwujemy w inwestowaniu pewne odejście od rynku akcji, co nie stanowi dobrego środowiska do tworzenia nowych rozwiązań w tym obszarze (rysunek 10). 
Rysunek 10. Skumulowane saldo wpłat i umorzeń w funduszach typowo akcyjnych na tle indeksu WIG (oś lewa indeks WIG, oś prawa saldo w mln PLN)

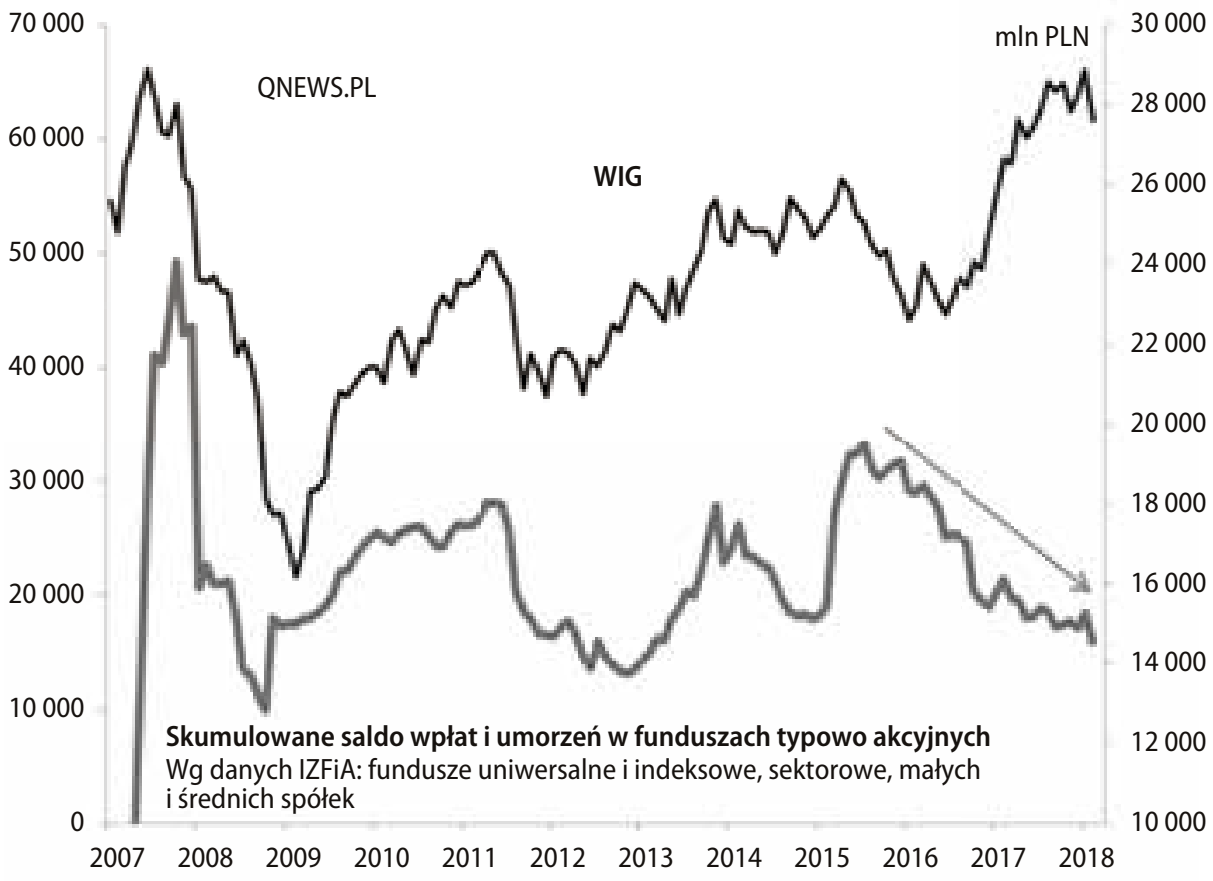

Źródło: [https://www.analizy.pl/fundusze/wiadomosci/23570/quercus-tfi\%3A-krwotok-funduszy-akcyjnych.html].

Rysunek 11. Wskaźnik recyklingu w Europie w 2015 r.

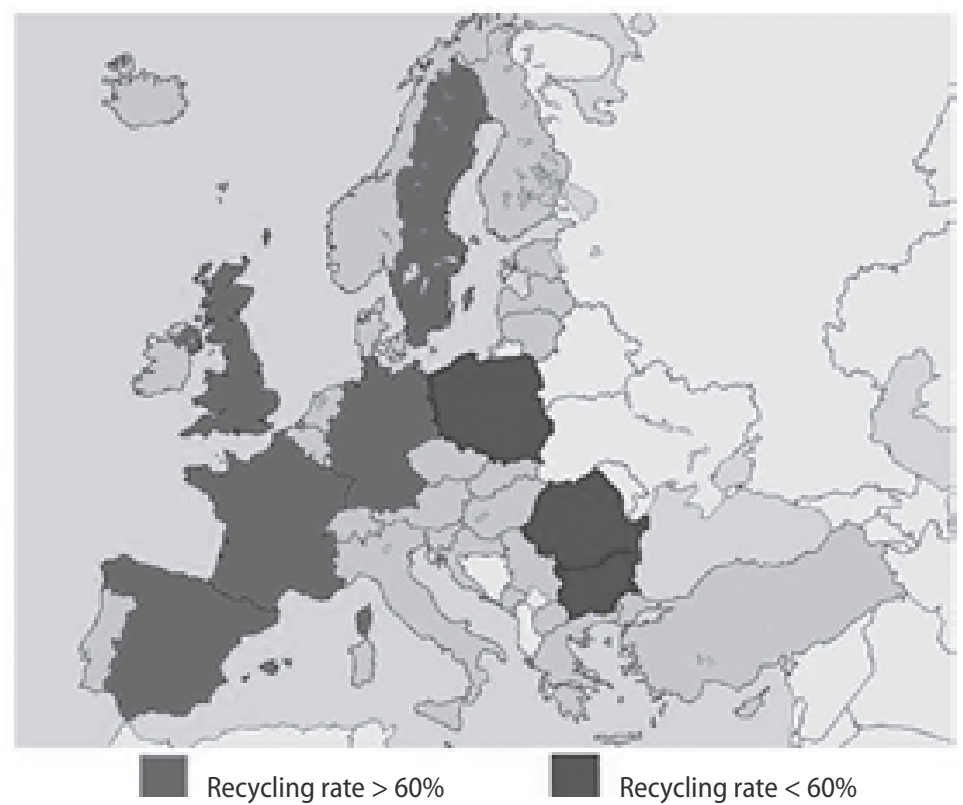

Źródło: [http://impactpaperec.eu/en/best-practices/introduction-objectives-of-the-handbook/]. 
Trudność sprawia analizowanie szerokich agregatów, dlatego autorzy postanowili posłużyć się swego rodzaju pochodnymi wrażliwości społeczeństwa na aspekty ekologiczne, co powinno się przekładać na dostrzeganie problemów, z których zrodziło się inwestowanie zrównoważone. Przykładem jest wskaźnik recyklingu, pokazujący, które kraje inwestują w ochronę środowiska. Poziom wskaźnika recyklingu w Polsce jest poniżej średniej europejskiej (rysunek 11). Nie oznacza to, że próby zmiany zachowania inwestorów nie są podejmowane, co zostanie opisane w dalszej części artykułu. Jednak widać, że otoczenie w postaci wystarczającej świadomości społeczeństwa nie jest temu sprzyjające.

\subsection{Działania w Polsce w zakresie inwestowania zrównoważonego}

W Polsce nie ma rozwiniętej kultury inwestowania w zgodzie z założeniami ESG. Wynika to $\mathrm{z}$ braku odpowiednio rozwiniętej grupy instrumentów finansowych - w chwili pisania niniejszego artykułu istnieją tylko 2 fundusze NN Investment Partners, które w sposób jednoznaczny inwestują zgodnie z wytycznymi zrównoważonego inwestowania. Nie sposób precyzyjnie ocenić ich popularności, gdyż oba istnieją od wielu lat, wcześniej w ramach innych strategii inwestycyjnych. Z tego powodu ich aktywa wynoszą ponad $160 \mathrm{mln}$ zł. Jeden z funduszy ma zasięg globalny i nieco ponad $20 \mathrm{mln}$ zł pod zarządzaniem, drugi jest rozwiązaniem lokalnym. Ma on zdecydowanie większe aktywa, przy czym należy zauważyć, że portfel ten jako jedną z pozycji zawiera akcje PKN Orlen (niecałe 5\%). Spółka paliwowa, w oczach wielu inwestorów, może nie wypełniać przesłanek odpowiedzialnego inwestowania. Dodatkowo opłaty bieżące przekraczają tutaj 3,5\% w skali roku, co należy uznać za wysoki poziom. Innym przykładem jest projekt Giełdy Papierów Wartościowych w Warszawie S.A. (GPW SA) pod nazwą RESPECT Index. Jego celem było wyłonienie z warszawskiej giełdy tych spółek, które wypełniają pewne przesłanki zarządzania zrównoważonego i odpowiedzialnego. Zgodnie z wynikami ankiety już w 2016 r. 46\% respondentów, którymi byli przedstawiciele najważniejszych instytucji finansowych, uwzględnia czynniki ESG w procesie podejmowania decyzji, stąd też indeks ten powinien mieć praktyczne znaczenie. Warto zauważyć, że punktem wyjścia jest tutaj płynność, co w przypadku polskiego rynku kapitałowego znacząco ogranicza wybór. Poza tym podmioty wchodzące w skład indeksu przechodzą jeszcze dwa etapy selekcji do indeksu - relacji inwestorskich (etap drugi) i właściwy audyt ESG (etap trzeci). Podmiotem wspierającym całe przedsięwzięcie jest Deloitte.

Warto zwrócić uwagę na wynik indeksu RESPECT względem indeksu szerokiego rynku $\mathrm{WIG}^{21}$ (rysunek 12). O ile w okresie od 31 grudnia 2008 r. (tj. od początku istnienia) do 28 grudnia 2018 r. stopa zwrotu z indeksu RESPECT przewyższała indeks WIG średniorocznie

\footnotetext{
21 Ten ostatni został wybrany przez autorów ze względu na podobieństwa konstrukcyjne, a więc jest także „dochodowy”, co oznacza, że jego stopa zwrotu, poza samym zachowaniem spółek składowych, bierze pod uwage także wszelkie pożytki wynikające z posiadanych akcji, czyli głównie dywidendy.
} 
o ponad 3\% (odpowiednio 10,82 i 7,8\%), o tyle od początku 2016 r. jego dynamika ulega pogorszeniu. Powodem niższych stóp zwrotu w ostatnim czasie jest m.in. brak w indeksie (potencjalnie kierującym się wytycznymi ESG) spółki CD Projekt S.A. Jest to jeden z najmocniejszych komponentów indeksów mWIG40 i WIG20 na przestrzeni ostatnich 5 lat. Spółka ta, w omawianym okresie, zwiększyła swoją kapitalizację przeszło 20-krotnie.

Rysunek 12. Notowania indeksu Respect vs WIG w okresie 2009-2019 (start = 100)

Porównanie wykresów indeksu RESPECT i WIG

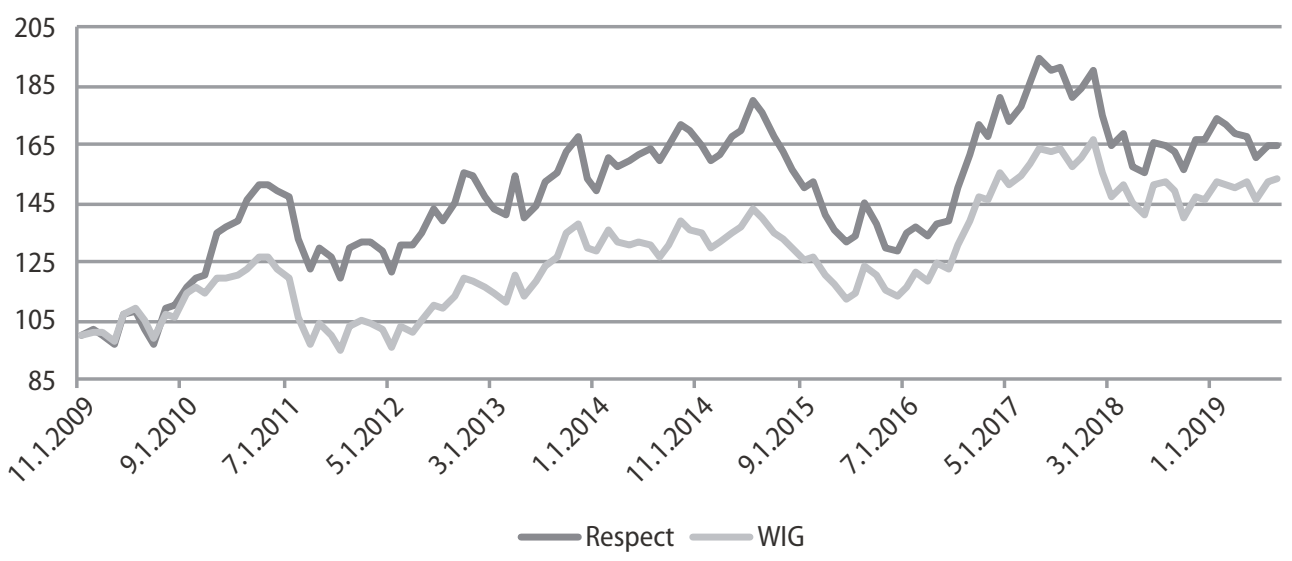

Źródło: opracowanie własne na podstawie [stooq.pl].

Idea tworzenia indeksu spółek inwestujących zgodnie z wytycznymi ESG jest słuszna i GPW S.A., jako organizator obrotu na regulowanym rynku giełdowym w Polsce, jest zapewne właściwą instytucją do tego typu działań. Choć w przypadku np. Stanów Zjednoczonych owe indeksy tworzone są przez niezależne podmioty, jednak w Polsce taki ekosystem rynkowy nie wykształcił się. Oficjalnie trudno znaleźć uzasadnienie dla przyjęcia przez GPW akurat takiego modelu konstrukcji indeksu. Można domniemywać, że kluczowa była tu obawa, iż zbyt ostre kryteria doboru spółek mogłyby spowodować, iż indeks byłby oparty na małej ich liczbie o bardzo ograniczonej płynności, a co za tym idzie, byłby niereplikowalny.

Szerokie kryteria konstrukcji sprawiły, że do indeksu trafiły spółki wątpliwe pod kątem ich społecznej odpowiedzialności. Takimi przykładami, ze względu na profil działalności, są: Lubelski Węgiel „Bogdanka” S.A. [Norges 2016a] i Jastrzębska Spółka Węglowa S.A. [Norges 2016b]. Co ciekawe, obie spółki zostały wykluczone ze spektrum inwestycyjnego przez Norges Bank Investment Management ${ }^{22}$, jednego z liderów w inwestowaniu zrównoważonym, co pokazuje zupełnie różne podejście do oceny jakości spółki przez pryzmat kryteriów ESG. Czy zatem próby tworzenia odpowiednich indeksów stanowią rzeczywisty krok ku krzewieniu kultury inwestowania społecznie odpowiedzialnego w Polsce?

\footnotetext{
22 Norges Bank - część norweskiego banku centralnego, który zajmuje się zarządzaniem globalnym funduszem emerytalnym; w Polsce inwestując na GPW poprzez oddelegowanie mandatu lokalnym TFI.
} 
Projektem konkurencyjnym do RESPECT Index jest prowadzone od 2010 r. przez Stowarzyszenie Emitentów Giełdowych badanie, objęte patronatem Komisji Nadzoru Finansowego, o nazwie „Analiza ESG spółek w Polsce”. Warto wspomnieć, że jedynie 30-40 spółek wypełniło w jakimkolwiek stopniu nowe zasady raportowania. Niestety, wyniki badań nie są upubliczniane, przez co użyteczność całego procesu jest dla inwestorów ograniczona.

Wart odnotowania jest fakt, że w Polsce obowiązuje już Standard Informacji Niefinansowych, ale przyjęte założenia są trudne w interpretacji (istotność niektórych parametrów musi samodzielnie określać zarząd danej spółki). Dodatkowo należy tutaj nadać kontekst branży. Z drugiej strony, zużycie materiałów, energii czy wody bądź wskazanie podziału pracowników ze względu chociażby na płeć można uznać za dość jednoznaczne i porównywalne, a tego typu informacje coraz częściej podlegają standaryzacji w raportowaniu ${ }^{23}$.

Tak niejednoznaczny obraz - z jednej strony sprzyjające otoczenie globalne i zmieniające się przepisy prawa, z drugiej brak realnego przełożenia na wzrost inwestycji zrównoważonych w Polsce - jest dość zaskakujący. Wydaje się, że wynika to z wciąż wczesnego poziomu rozwoju polskiego rynku i świadomości inwestorów, co jest charakterystyczne dla rynków wschodzących, do których Polska - według wielu kryteriów - wciąż należy.

Inną grupą instrumentów opartych na założeniach inwestowania zrównoważonego są produkty strukturyzowane, a więc takie, których elementem jest instrument pochodny. Przykładem może być tutaj produkt inwestycyjny oparty na indeksie Solactive Sustainable Development Goals World RC 8EUR Index, emitowany przez BNP Paribas Issuance B.V. i dystrybuowany w Polsce przez lokalne biuro maklerskie BGŻ BNP. Poziom skomplikowania produktu jest wysoki, gdyż składowymi wspomnianego indeksu są Solactive Sustainable Development Goals World Eurindex oraz Goals World Eur Cash. O ile założenia należy tutaj ocenić pozytywnie, o tyle zrozumienie filozofii stojącej za doborem konkretnych spółek do portfela należy uznać za mało przejrzysty, chociażby ze względu na brak odpowiedniej polityki inwestycyjnej w języku polskim.

\section{Podsumowanie}

W inwestycjach zrównoważonych, stanowiących już ponad 25\% wartości wszystkich aktywów inwestycyjnych świata, czynniki behawioralne przeważają nad kryteriami finansowymi. Budowa portfela inwestycyjnego to selekcja spółek przez ocenę ich odpowiedzialnego (etycznego) działania i budowy tzw. dobra społecznego. Przy doborze aktywów najczęściej stosuje się strategie oparte na selekcji negatywnej, integracji ESG lub na normach oraz zaangażowaniu korporacyjnym i akcjonariuszy.

\footnotetext{
23 Przykładem dobrej praktyki w tym zakresie są standardy GRI (Sustainability Reporting Standards), które są próbą stworzenia międzynarodowego wzorca raportowania ekonomicznych, środowiskowych oraz społecznych aspektów funkcjonowania przedsiębiorstw.
} 
Konsumenci są w stanie płacić więcej za te produkty, które pozytywnie oddziałują na środowisko naturalne czy społeczeństwo, dlatego też powinien się kreować popyt na inwestycje zrównoważone. Ponad $90 \%$ badań dotyczących inwestycji społecznie odpowiedzialnych nie wskazało negatywnego wpływu stosowania kryteriów ESG na wyniki finansowe spółek. Ponadto implementacja kryteriów ESG w działalności spółek przynosi im w praktyce wymierne korzyści finansowe. Fundusze pasywne oparte na indeksach ESG historycznie cechowały się podobną relacją zysku do ryzyka co ETF-y, oparte na szerokich indeksach. Ponadto uwzględnianie czynników ESG przy budowie portfela inwestycyjnej może zmniejszyć jego zmienność. Wszystkie te czynniki sprawiają, że rynek inwestowania zrównoważonego jest potrzebny i będzie się dynamicznie rozwijać. Zarządzający powinni zatem zwracać uwagę na to, czy spółki, które dobierają do portfeli inwestycyjnych, stosują kryteria ESG, ponieważ potencjalnie może to poprawić stopy zwrotu i obniżyć zmienność zarządzanych portfeli.

Do najważniejszych inicjatyw z zakresu inwestowania zrównoważonego w Polsce zaliczyć należy stworzenie RESPECT Index, badania nad kryteriami ESG prowadzone przez Stowarzyszenie Emitentów Giełdowych oraz wprowadzenie Standardu Informacji Niefinansowych. Niejed noznaczny obraz rynku inwestowania zrównoważonego w Polsce wynika z wczesnego poziomu rozwoju polskiego rynku, niskiej świadomości inwestorów oraz niskiego poziomu zaufania Polaków do instytucji finansowych.

Z punktu widzenia inwestora rozpoznanie inwestycji zrównoważonych może stanowić wyzwanie. Główną trudnością jest poprawna ocena, czy przyjęcie przez dany fundusz kryteriów zrównoważonego inwestowania jest zabiegiem marketingowym, odpowiadającym na zapotrzebowanie rynku i opartym wyłącznie na zapisie statutowym, czy też faktycznie ważnym elementem procesu inwestycyjnego. Potencjalnym kierunkiem dalszych badań może być bardziej szczegółowa analiza faktycznego zastosowania kryteriów ESG w doborze składników portfela inwestycyjnego, a także krytyczna ocena modelu ESG stosowanego przez firmę Morningstar. Wsparciem dla inwestorów w selekcji funduszy zgodnych z SRI są serwisy branżowe, takie jak Morningstar czy MSCI ESG Fund Metrics.

\section{Bibliografia}

\section{Wydawnictwa zwarte oraz artykuły prasowe i okolicznościowe}

1. Attig N. [2013], Corporate Social Responsibility and Credit Ratings, „Journal of Business Ethics”, vol. 117, iss. 4, s. 679-694.

2. Bauer R., Hann D. [2010], Corporate Environmental Management and Credit Risk, Maastricht University, Maastricht.

3. Chava S. [2011], Environmental Externalities and Cost of Capital, Georgia Institute of Technology, Atlanta.

4. Duliniec A. [2015], Inwestowanie społecznie odpowiedzialne - przejściowa moda czy trwała tendencja?, Zeszyty Naukowe Uniwersytetu Ekonomicznego w Krakowie, 937/2015, s. 39-49. 
5. El Ghoul S., Guedhami O., Kim H., Park K. [2016], Corporate Environmental Responsibility and the Cost of Capital: International Evidence, „Journal of Business Ethics”, vol. 149(2), s. 335-361.

6. Friede G., Busch T., Bassen A. [2015], ESG and Financial Performance: Aggregated Evidence from more than 2000 Empirical Studies, „Journal of Sustainable Finance \& Investment”, vol. 5, iss. 4, s. 210-233.

7. Fulton M., Kahn B., Sharples C. [2012], Sustainable Investing: Establishing Long-Term Value and Performance, Deutsche Bank's Climate Change Advisors Report.

8. Goff S. [2006], Ethical Funds, „Financial Times”, 14 July, https://www.ft.com/content/ d603b526-131e-11db-9d6e-0000779e2340

9. Hale J. [2016], Sustainable Investing Research Suggests No Performance Penalty, Morningstar Manager Research, November.

10. Hale J. [2017], The Morningstar Sustainability Rating: Helping Investors Evaluate the Sustainability of Portfolios, „Investments\&Wealth Monitor”, Nov-Dec.

11. Hale J. [2018], Sustainable Funds U.S. Landscape Report, Morningstar Research, January, https://corporate1.morningstar.com/ResearchLibrary/article/846182/sustaina-ble-funds-us-landscape-report/

12. Hysa B. [2016], Zarządzanie różnorodnościa pokoleniową, „Zeszyty Naukowe Politechniki Śląskiej, Seria: Organizacja i Zarzadzanie”, z. 97, nr kol. 1964, s. 388.

13. Jamróz P. [2017], Struktura rynku funduszy społecznie odpowiedzialnych w wybranych krajach europejskich, „Finanse, Rynki Finansowe, Ubezpieczenia”, nr 5(89), cz. 2.

14. Kłos L. [2015], Świadomość ekologiczna Polaków - przegląd badań, „Studia i Prace Wydziału Nauk Ekonomicznych i Zarządzania”, nr 42, t. 2, s. 38.

15. Martysz C. [2013], Zarys problematyki finansów islamskich, „Studia i Prace Kolegium Zarządzania i Finansów SGH", 128.

16. Martysz C., Rzeszutek M. [2016], Problem informacji cenotwórczych w kontekście nowych unijnych obowiązków informacyjnych spółek publicznych, w: Przełamywanie dysonansów poznawczych jako czynnik stymulowania rozwoju nauk o finansach, red. J. Ostaszewski, Oficyna Wydawnicza SGH w Warszawie, Warszawa.

17. Rogall H. [2010], Ekonomia zrównoważonego rozwoju, Wydawnictwo Zysk i S-ka, Poznań.

18. Sparkes R. [2002], Socially Responsible Investment: The Global Revolution, John Wiley\&Sons, Chichester.

\section{Materiały internetowe i raporty}

1. Blackrock Investment Institute [2018], Sustainable Investing: A Why Not Moment, https:// www.blackrock.com/corporate/literature/whitepaper/bii-sustainable-investing-may-2018-us. pdf, dostęp 1.07.2019.

2. Cibor K., Muzińska A. [2011], Impact investing - czym jest inwestowanie zaangażowane społecznie, www. ekonomiaspoleczna.pl/wiadomosc/672578.html.

3. Giełda Papierów Wartościowych w Warszawie S.A., https://www.gpw.pl/-aktualnosc?cmn_ $\mathrm{id}=59290$ \& title=RESPECT + Index, dostęp 1.07.2019.

4. GIIN Research Team [2018], Annual Impact Investor Survey, June 2018. 
5. GSIA, Global Sustainable Investment Alliance [2012; 2016; 2018], Global Sustainable Investment Review, http://www.gsi-alliance.org, dostęp 1.07.2019.

6. http://impactpaperec.eu/en/best-practices/introduction-objectives-of-the-handbook/

7. https://www.analizy.pl/fundusze/wiadomosci/23570/quercus-tfi\%3A-krwotok-funduszy-akcyjnych.html, dostęp 1.07.2019.

8. https://www.innovacap.com/pl/strategia/odpowiedzialne-inwestowanie/, dostęp 1.07.2019.

9. https://www.ishares.com/uk/individual/en/themes/sustainable-investing, dostęp 1.07.2019.

10. https://www.msci.com/esg-fund-metrics, dostęp 1.07.2019.

11. https://www.schroders.com/en/insights/economics/esg-in-passive-let-the-buyer-beware/, dostęp 1.07.2019.

12. ImpactBase, https://thegiin.org/impact-investing/need-to-know/\#impact-investing-funds.

13. Intertrust, Privat Equity Market 2018, https://www.intertrustgroup.com/ /media /Files/I/ Intertrust-Group/Intertrust\%20Private\%20Equity\%20Report\%20-\%20final.pdf

14. J.P. Morgan [2016], ESG - Environmental, Social \& Governance Investing: A Quantitative Perspective of How ESG Can Enhance your Portfolio, https://yoursri.com/media-new/download/ jpm-esg-how-esg-can-enhance-your-portfolio.pdf

15. J.P. Morgan Emerging Markets Equity Fund [2018], Summary Prospectus, March 1, https:// prospectus-express.broadridge.com/summary.asp? doctype $=$ spro\&client $=-\mathrm{id}=$ jpmll\&fundid$4812 \mathrm{a} 0607$

16. KPF, Konfederacja Przedsiębiorstw Finansowych w Polsce [2017], Moralność finansowa Polaków, http://www.kpf.pl/pliki/raporty/moralnosc-finansowa-Polakow-raport-2017.pdf

17. Morningstar [2016], The Morningstar Sustainability Rating, http://www.morningstar.com/lp/ sustainability-rating?cid=OSM_LNK, dostęp 1.07.2019.

18. Morningstar [2018], Sustainable Funds U.S. Landscape Report, https://www.morningstar.com/ lp/sustainable-funds-landscape-report, dostęp 1.07.2019.

19. NBP [2017], Zasobność gospodarstw domowych w Polsce. Raport z badania 2016 r., Departament Analiz Ekonomicznych i Departament Stabilności Finansowej.

20. Nielsen [2015], Nielsen Global Survey of Corporate Social Responsibility, Q1, https://www. nielsen.com/us/en/insights/report/2015/the-sustainability-imperative-2/\#, dostęp 1.07.2019.

21. Norges Bank [2016a], Grounds for Decision - Product Based Coal Exclusions, https://www. nbim.no/contentassets/d99e60bdb5794272ae0df58d79da0d65/20160414-grounds-for-decision---product-based-coal-exclusions.pdf

22. Norges Bank [2016b], Grounds for Decision - Product-based Coal Exclusions, https://www. nbim.no/contentassets/08b0787eae8a4016bd06bfeba0067e32/grounds-for-decision---2nd-tranche-of-coal-exclusions.pdf

23. Stein C. [2018], Vanguard Plans to Start Its First ETFs Tied to ESG Investing, https://www. bloomberg.com/news/articles/2018-06-27/vanguard-plans-to-start-its-first-etfs-tied-to-esginvesting

24. The Morgan Stanley Institute for Sustainable Investing [2016], Sustainable Signals, The Asset Manager Perspective, Bloomberg, https://www.morganstanley.com/auth/con-tent/dam/msdotcom/en/assets/pdfs/Morgan_Stanley_ISI_Sustainable_Signals.pdf, dostęp 1.07.2019. 


\section{Sustainable Investment in Managing Investment Portfolio}

\section{Summary}

Sustainable investing consists in building an investment portfolio by selecting companies - issuers of investment assets, whose conduct is seen as responsible (ethical) and contributes to the building up of the so called social good. Sustainable investment has already exceeded $25 \%$ of the value of all global investment assets and the biggest assets in Europe are already managed in accordance with this approach. An investor may face difficulties in assessing whether the incorporation of a sustainable investment criterion into an investment fund's Statutes is just a marketing gimmick or a genuinely vital component of the investment policy. This paper aims at demonstrating the importance and impact of sustainable investing on investment portfolio management.

Over $90 \%$ of studies focused on socially responsible investment did not reveal any negative impact of ESG criteria (investing that respects environmental, social, and governance criteria) on the financial performance of companies. On the contrary, implementing ESG criteria to business practice, developing responsible investment policies and publishing reports on corporate performance bring concrete financial benefits to companies. Thus, sustainable investment market is necessary and it is highly likely that it will continue to develop dynamically. Major initiatives in sustainable investing in Poland include the creation of the RESPECT Index, a study on ESG criteria carried out by the Polish Association of Listed Companies [Stowarzyszenie Emitentów Giełdowych] and the adoption of Non-financial Information Statement.

Keywords: Socially responsible investing, sustainable investment, investment funds, SRI, ESG 